\title{
Survival of Nocardia corallina and Degradation of Constituents during Starvation
}

\author{
By J. G. ROBERTSON AND R. D. BATT \\ Applied Biochemistry Division, D.S.I.R. and Department of Biochemistry, Massey \\ University, Palmerston North, New Zealand
}

(Received 20 February 1973; revised 26 March I973)

\section{SUMMARY}

The survival of Nocardia corallina and the degradation of constituents were examined during periods of starvation. Organisms were harvested at the end of the growth phase and were starved, after resuspending in phosphate buffer containing $\mathrm{Mg}^{2+}$, with vigorous aeration at $30^{\circ} \mathrm{C}$. Viability fell gradually to $50 \%$ over a period of $480 \mathrm{~h}$. After $48 \mathrm{~h}$ of starvation the dry weight of the organisms was reduced by $35 \%$ and the $Q_{0_{2}}$ was decreased from Io to approximately $\mathrm{I}$. The fall in dry weight coincided with a decrease of microbial polysaccharide from $25 \%$ to $7 \%$ of the initial dry weight. After this degradation of polysaccharide there was a decrease in microbial protein and a release of ammonia into the supernatant. The contribution of different constituents to the total decrease in dry weight during a period of $240 \mathrm{~h}$ starvation was; polysaccharide, $40 \%$; protein, $25 \%$; RNA, $6 \%$; total fatty acids, $5 \%$. Loss of viability could not be directly correlated with the utilization of any particular constituent.

\section{INTRODUCTION}

Soil micro-organisms in their natural environment are subjected to periodic deficiencies of nutrient, thus the survival of the species could depend on the colonization of a new ecological niche. Brock (I966) has listed resistance to starvation in dilute medium as one possible morphological or physiological adaptation which might aid dispersal. Clark (1967) has suggested that many organisms in the soil are in a resting or dormant state and hence may survive by utilizing endogenous reserves (Dawes \& Ribbons, I962; Lamanna, I963). However, apart from an increased capacity to survive in soil, which can be related to sporogenesis (Sneath, 1962) or possibly to desiccation or low temperature (Brock, I966), there is little direct evidence to support the suggestion that soil bacteria can exist in a resting state (Park, 1965) even though approximately $75 \%$ of soil bacteria (excluding actinomycetes) are non-spore-formers (Clark, 1967).

Of those studies which have examined the survival capacity of micro-organisms, only a few have been concerned with the autochthonous group of soil micro-organisms. This group includes organisms which grow relatively slowly and appear at a late stage in the ecological succession which occurs during the decomposition of plant residues (Alexander, 1964). The group includes species of actinomycetes (Conn, I948; Waksman, I959; Alexander, 1964), some of which show exceptional catabolic abilities by degrading a wide range of complex materials typical of those produced during animal and plant decay.

The soil actinomycete Nocardia corallina is considered to be typical of the autochthonous group (Alexander, 1964; Clark, 1967). This organism shows a high degree of biochemical versatility in the range of substrates it can oxidize (Midwinter, I962). It is capable of growth on compounds commonly present in soils which contain decaying plant and animal matter 
(Tepper \& Karyagina, I 966), grows relatively slowly, demonstrates a low rate of endogenous metabolism (Midwinter \& Batt, 1960) and appears to be somewhat resistant to starvation (Webb \& Clark, 1957).

A high resistance to starvation has been demonstrated in species of Arthrobacter (Zevenhuizen, 1966; Ensign, 1970) which, like Nocardia, are also regarded as autochthonous organisms (Gordon, 1966; 1967). The pattern of endogenous metabolism observed in Arthrobacter crystallopoietes was similar to that of other organisms which lose viability relatively quickly, but the rate of catabolism was lower (Boylen \& Ensign, 1970). It was suggested that the lower rate of catabolism provided an explanation for the increased resistance to starvation.

In the present study, Nocardia corallina was cultured in well aerated glucose medium in which growth was characterized by division of organisms 2 to $4 \mu \mathrm{m}$ in length (Clark \& Frady, I957; Brown \& Clark, I966). Organisms were starved by resuspending in phosphate buffer containing $\mathrm{Mg}^{2+}$. Changes in viable and total counts and in the level of constituents were examined during periods of incubation at $30{ }^{\circ} \mathrm{C}$.

\section{METHODS}

Organism and culture methods. Nocardia corallina isolated by Batt \& Woods (I95I) was maintained on glucose-yeast extract-agar slants at $2{ }^{\circ} \mathrm{C}$. Liquid cultures were grown in I 1 cleated flasks (Corman et al. 1957) containing $300 \mathrm{ml}$ of medium by incubating at $30{ }^{\circ} \mathrm{C}$ with rotary shaking at $\mathrm{I} 40 \mathrm{rev} . / \mathrm{min}$. Cleated flasks were used to improve the efficiency of aeration and to disperse clumps which form in liquid cultures of $N$. corallina (Webb \& Clark, I957; Clark, I958).

The medium contained $(\mathrm{g} / \mathrm{l})$ : Vitamin $\mathrm{B}_{1}, 0.025 ;\left(\mathrm{NH}_{4}\right)_{2} \mathrm{SO}_{4}, 3.0 ; \mathrm{MgSO}_{4} .7 \mathrm{H}_{2} \mathrm{O}, 0.10$; $\mathrm{KH}_{2} \mathrm{PO}_{4}, 13.6$; it was adjusted to $\mathrm{pH} 7.0$ by addition of $5 \mathrm{M}-\mathrm{NaOH}$. The medium was sterilized by autoclaving at ${ }_{5} \mathrm{lb} / \mathrm{in}^{2}$ for $\mathrm{I}_{5} \mathrm{~min}$. Glucose solution $(\mathrm{I} 5 \% \mathrm{w} / \mathrm{v})$, also sterilized by autoclaving, was added aseptically to give a final concentration of glucose in the medium of $0.75 \%(\mathrm{w} / \mathrm{v})$. For routine preparation of cultures a single flask was inoculated from a slant which had been stored at $2{ }^{\circ} \mathrm{C}$ for no longer than $48 \mathrm{~h}$ after preparation. The flask culture was incubated until the optical density at $660 \mathrm{~nm}$ reached half maximum when samples were transferred aseptically to flasks containing fresh medium. Growth of organisms continued in the fresh medium with a doubling time of $5 \mathrm{~h}$ until maximum optical density was reached when organisms were harvested. At harvesting, the medium was $\mathrm{pH} 6.7$ and the yield of organisms approximately $3 \mathrm{mg}$ dry $\mathrm{wt} / \mathrm{ml}$ of medium.

Preparation of starved suspensions. Organisms were harvested under aseptic conditions by centrifugation at $2000 \mathrm{~g}$ for $7 \mathrm{~min}$ at $2{ }^{\circ} \mathrm{C}$ and washed twice with phosphate buffer (o. I M- $\mathrm{KH}_{2} \mathrm{PO}_{4}$, adjusted to $\mathrm{pH} 7.0$ with $5 \mathrm{M}-\mathrm{NaOH}$, containing $4 \times 1 \mathrm{I}^{-4} \mathrm{M}^{-} \mathrm{MgSO}_{4}$ ). The pellets, approximately $900 \mathrm{mg}$ dry wt, were resuspended in $300 \mathrm{ml}$ of sterile phosphate buffer per cleated flask. Flasks containing suspensions of organisms were weighed and incubated at $30{ }^{\circ} \mathrm{C}$ with shaking at $140 \mathrm{rev}$. $/ \mathrm{min}$. During prolonged incubation loss of water caused by evaporation was compensated by addition of sterile distilled water.

Analytical procedures. Total numbers of organisms were determined by using a counting chamber (Thoma). Clusters of organisms were dispersed by including the detergent Teepol (Shell Oil Company) $(0.5 \%, \mathrm{v} / \mathrm{v})$ in the phosphate buffer used for preparing dilutions. Teepol rendered the organisms non-viable but lysis was not observed.

Because counts of viable organisms were complicated by the presence of clusters of organisms in the starved suspensions, counts of viable clusters were determined by the slide 
culture method of Postgate, Crumpton \& Hunter (196I). The agar medium for the slide cultures was as that used for liquid cultures except for the following additions per 1 of medium; yeast extract (Oxoid) 0.5 g; Agar (Davis) $10.0 \mathrm{~g}$; also $\mathrm{KH}_{2} \mathrm{PO}_{4}$ was lowered to 3.40 $\mathrm{g} / \mathrm{l}$. Clusters were partially dispersed by including Tween $80(0.5 \%, \mathrm{v} / \mathrm{v})$ in the phosphate buffer used for diluting suspensions. Although Tween 80 was not as effective as Teepol for dispersing clusters, it appeared to have no effect on viability. Non-viable organisms, whether occurring singly or in clusters, could be distinguished from viable organisms by incubating the slide cultures for $\mathrm{I} 6$ to $20 \mathrm{~h}$ at $30^{\circ} \mathrm{C}$ when non-viable clusters consisted of several organisms, 2 to $4 \mu \mathrm{m}$ in length, adhering to each other in random arrangement, whereas colonies resulting from viable organisms consisted of branching rods 8 to $15 \mu \mathrm{m}$ in length.

The viability of individual organisms was estimated from the cluster viability and the cluster size distribution by using formulae derived on the basis that dead organisms were randomly distributed through clusters of all sizes (Thomas, Doughty, Fletcher \& Robertson, 1972). The cluster-size distribution, defined as the proportion of organisms in clusters of different sizes, was determined by examining slide cultures before growth of the organisms had occurred.

Dry weights of organisms, harvested at different times during growth and starvation, were determined by drying to constant wt after heating to $\mathrm{I}_{20}{ }^{\circ} \mathrm{C}$ and cooling over $\mathrm{P}_{2} \mathrm{O}_{5}$. The relation was established between the dry weights and optical density of original suspensions of organisms; thereafter estimations of dry wt were made by measuring the optical density of suspensions of organisms at $660 \mathrm{~nm}$. Before determining optical density, samples were diluted with distilled water and thoroughly dispersed with a teflon plunger homogenizer.

Respiratory quotients were determined by direct Warburg respirometry (Umbreit, Burris \& Stauffer, 1964).

Estimates of total nitrogen were made by the micro-Kjeldahl method and total protein by the method of Stickland (I95I). Microbial protein was determined on pellets obtained by centrifuging suspensions at $12000 \mathrm{~g}$ for $10 \mathrm{~min}$ at $2{ }^{\circ} \mathrm{C}$ and then twice resuspending in distilled water and recentrifuging.

Microbial fatty acids were extracted from washed organisms by the method of Salton (I953) and were assayed by chromate oxidation (Amenta, 1964).

Total hexose was determined using the anthrone method (Bailey, 1967) with glucose as standard.

Microbial reducing sugar was estimated by the method of Nelson (1944) after acid

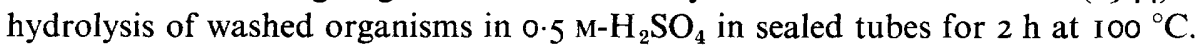

Ribonucleic acid was determined by the method of Munro \& Fleck (I966).

Extracts of washed organisms (Holden, 1962), were used to determine levels of microbial free amino acids (Rosen, 1957), and microbial free reducing sugars (Nelson, 1944).

Materials excreted into the extracellular medium during starvation were determined on supernatants obtained by centrifuging suspensions at $12000 \mathrm{~g}$ for $10 \mathrm{~min}$ at $2{ }^{\circ} \mathrm{C}$.

Ammonia was determined by the method of Conway (1947) or by using Nessler's reagent (Umbreit et al. 1964).

\section{RESULTS}

Morphology of Nocardia corallina. Growth of Nocardia corallina on the surface of agar was characterized by the formation of branching rods 10 to $15 \mu \mathrm{m}$ in length. In liquid cultures, organisms were predominantly 2 to $4 \mu \mathrm{m}$ in length and 0.8 to $\mathrm{I} \cdot 2 \mu \mathrm{m}$ in diameter. Heavy clumping did not occur, although it was observed, by using visible light microscopy, that many organisms were aggregated to a small extent. In a typical suspension in phosphate 


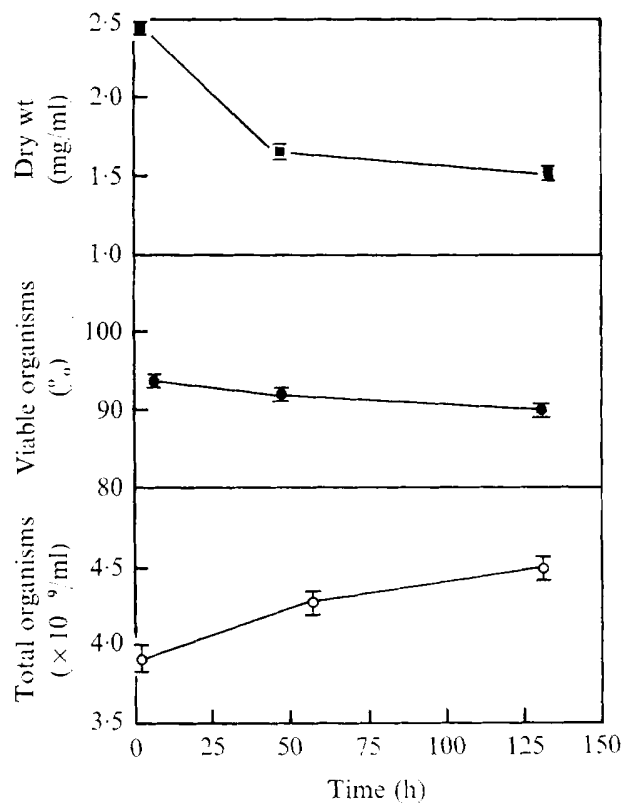

Fig. I

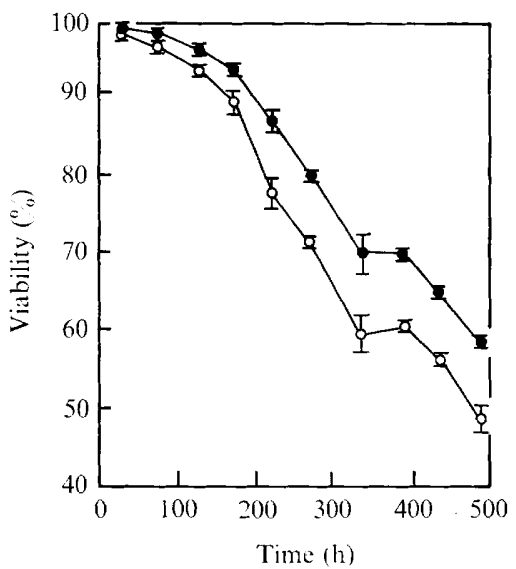

Fig. 2

Fig. I. Effect of starvation on suspensions of Nocardia corallina. Organisms suspended in phosphate buffer were incubated at $30^{\circ} \mathrm{C}$ with shaking for $13 \mathrm{I} \mathrm{h}$. The means and standard errors of results of single analyses on each of six flasks are presented. Viability of individual organisms was estimated from the cluster viability by using formulae (Thomas et al. 1972). Dry wt ( $\mathbf{\square}$ ); viable organisms (O); total organisms $(\bigcirc)$.

Fig. 2. Effect of starvation on suspensions of Nocardia corallina. Organisms suspended in phosphate were incubated at $30^{\circ} \mathrm{C}$ with shaking for $240 \mathrm{~h}$. The means and standard errors of results of duplicate analyses on each of three suspensions are presented. Viability of individual organisms was determined from the cluster viability by using formulae (Thomas et al. 1972). Viable clusters (O); viable organisms $(\bigcirc)$.

buffer, containing Tween 80, the degree of aggregation was as follows; single organisms $54 \%$, pairs $33 \%$, triplets $6 \%$, the remainder were in clusters containing more than three organisms.

Changes in dry weight and viable and total counts during starvation. Cultures of Nocardia corallina left to incubate at $30{ }^{\circ} \mathrm{C}$ for a period of $48 \mathrm{~h}$ after reaching maximum optical density showed a loss in dry wt of $40 \%$ of the maximum yield. This loss was also observed with organisms from cultures harvested at full growth and starved by resuspending in phosphate buffer at $30{ }^{\circ} \mathrm{C}$ (Fig. I). Over a period of $130 \mathrm{~h}$ dry wt was reduced by $35 \%$. Most of this reduction took place during the first $50 \mathrm{~h}$ of starvation. The number of viable organisms was reduced by $10 \%$ during the $130 \mathrm{~h}$ period and there was a rise in the total number of organisms which was possibly the result of fragmentation of organisms divided by cross-septa.

The numbers of Nocardia corallina surviving starvation in phosphate buffer fell $50 \%$ after a period of $480 \mathrm{~h}$ (Fig. 2).

Changes in respiratory activity. The respiratory activity of starved organisms fell rapidly during the first $45 \mathrm{~h}$ after resuspension to approximately $\mathrm{x} \mu \mathrm{l} \mathrm{O} 2 / \mathrm{mg}$ dry wt $/ \mathrm{h}$. This decline coincided with the initial fall in dry wt (Table I). Respiratory quotients showed values greater than $\mathrm{I}$ at all stages during starvation. 
Table I. Respiration by suspensions* of starved Nocardia corallina

\begin{tabular}{|c|c|c|c|c|c|}
\hline $\begin{array}{l}\text { Starvation } \\
\text { time (h) }\end{array}$ & Flask & $\underset{(\mu \mathrm{l} / \mathrm{ml} / \mathrm{h})}{Q_{\mathrm{O}_{2}}}$ & $\underset{(\mu \mathrm{l} / \mathrm{ml} / \mathrm{h})}{Q_{\mathrm{Co}_{2}}}$ & RQ† & $\begin{array}{l}\text { Dry wt } \\
(\mathrm{mg} / \mathrm{ml})\end{array}$ \\
\hline 3 & $\begin{array}{l}\text { I } \\
2\end{array}$ & $\begin{array}{l}33 \cdot 0 \\
32 \cdot 6\end{array}$ & $\begin{array}{l}38 \cdot 0 \\
42 \cdot 1\end{array}$ & $\begin{array}{l}1 \cdot 15 \\
I \cdot 29\end{array}$ & $\begin{array}{l}2 \cdot 80 \\
3 \cdot 12\end{array}$ \\
\hline 22 & $\begin{array}{l}1 \\
2\end{array}$ & $\begin{array}{l}4 \cdot 45 \\
4 \cdot 60\end{array}$ & $\begin{array}{l}4 \cdot 87 \\
5 \cdot 13\end{array}$ & $\begin{array}{l}I .09 \\
1.05\end{array}$ & $\begin{array}{l}2 \cdot 34 \\
2 \cdot 58\end{array}$ \\
\hline 45 & $\begin{array}{l}\text { I } \\
2\end{array}$ & $\begin{array}{l}2 \cdot 53 \\
2 \cdot 97\end{array}$ & $\begin{array}{l}2 \cdot 65 \\
3 \cdot 17\end{array}$ & $\begin{array}{l}1 \cdot 05 \\
1 \cdot 08\end{array}$ & $\begin{array}{l}2 \cdot 24 \\
2 \cdot 47\end{array}$ \\
\hline 70 & $\begin{array}{l}\text { I } \\
2\end{array}$ & $\begin{array}{l}2 \cdot 87 \\
2 \cdot 83\end{array}$ & $\begin{array}{l}3 \cdot 26 \\
3 \cdot 64\end{array}$ & $\begin{array}{l}I \cdot 15 \\
I \cdot 34\end{array}$ & $\begin{array}{l}2 \cdot 11 \\
2 \cdot 19\end{array}$ \\
\hline 93 & $\begin{array}{l}\text { I } \\
2\end{array}$ & $\begin{array}{l}2 \cdot 75 \\
3 \cdot 02\end{array}$ & $\begin{array}{l}3 \cdot 04 \\
3 \cdot 26\end{array}$ & $\begin{array}{l}I \cdot 10 \\
1 \cdot 07\end{array}$ & $\begin{array}{l}2 \cdot 04 \\
2 \cdot 15\end{array}$ \\
\hline 118 & $\begin{array}{l}\text { I } \\
2\end{array}$ & $\begin{array}{l}2 \cdot 24 \\
I \cdot 6 I\end{array}$ & $\begin{array}{l}3 \cdot 06 \\
2 \cdot 15\end{array}$ & $\begin{array}{l}1 \cdot 36 \\
1 \cdot 33\end{array}$ & $\begin{array}{l}2.02 \\
2 \cdot 11\end{array}$ \\
\hline
\end{tabular}

* Organisms suspended in phosphate buffer were incubated at $30^{\circ} \mathrm{C}$ with shaking for I $8 \mathrm{~h}$. Samples were transferred directly to Warburg manometer flasks for estimation of gas exchange rates.

$\dagger$ Respiratory quotient

Table 2. Degradation of constituents in starved Nocardia corallina

\begin{tabular}{|c|c|c|}
\hline & \multicolumn{2}{|c|}{$\begin{array}{l}\text { Constituent expressed as } \mathrm{mg} / \mathrm{ml} \\
\text { of suspension* (S.E.) }\end{array}$} \\
\hline & \multicolumn{2}{|c|}{ Starvation time $(\mathrm{h})$} \\
\hline onstituent & o & 118 \\
\hline ogen & $0.284(0.004)$ & $0.282(0.004)$ \\
\hline tant nitrogen & $0.005(0.001)$ & $0.044(0.002)$ \\
\hline ial protein & $\mathrm{I} .88(0.05)$ & $\mathrm{I} \cdot 5 \mathrm{I}(0.02)$ \\
\hline atant ammonia-nitrogen & $0.0005(0.0003)$ & $0.0339(0.0008)$ \\
\hline hexose & $0.72(0.02)$ & $0.14(0.01)$ \\
\hline tant hexose & $0.013(0.002)$ & $0.018(0.003)$ \\
\hline & $3.43(0.05)$ & I.94 (O.0I) \\
\hline
\end{tabular}

* Organisms suspended in phosphate buffer were starved by incubation at $30{ }^{\circ} \mathrm{C}$ for II $8 \mathrm{~h}$. The means and standard errors (s.E.) of results of duplicate analyses on each of three suspensions of $N$. corallina are presented.

Degradation of constituents and excretion of materials to the extracellular medium. Changes in the levels of microbial and supernatant constituents were examined over a I $8 \mathrm{~h}$ period (Table 2). There was a marked diminution of microbial hexose and microbial protein. Ammonia constituting $77 \%$ of the supernatant nitrogen was excreted.

To determine the relative rates of breakdown of constituents, samples were taken at intervals over $98 \mathrm{~h}$ starvation for the estimation of total hexose, total protein and microbial fatty acids (Fig. 3); a cluster viability of $95 \%$ was recorded at the end of this period. The rapid decline in dry wt during the first $27 \mathrm{~h}$ of starvation coincided with a fall in total hexose from $24 \%$ to $6 \%$ of the initial dry weight. Of the total fall in dry wt the breakdown of total hexose accounted for $56 \%$, total protein accounted for $21 \%$ and microbial fatty acids $7 \%$.

Changes in dry wt, microbial fatty acids, total protein and supernatant ammonia were examined over a period of $176 \mathrm{~h}$ (Fig. 4). Microbial fatty acids fell from $14 \%$ to $10 \%$ and protein from $35 \%$ to $27 \%$ of the initial dry wt. The amount of ammonia-nitrogen 


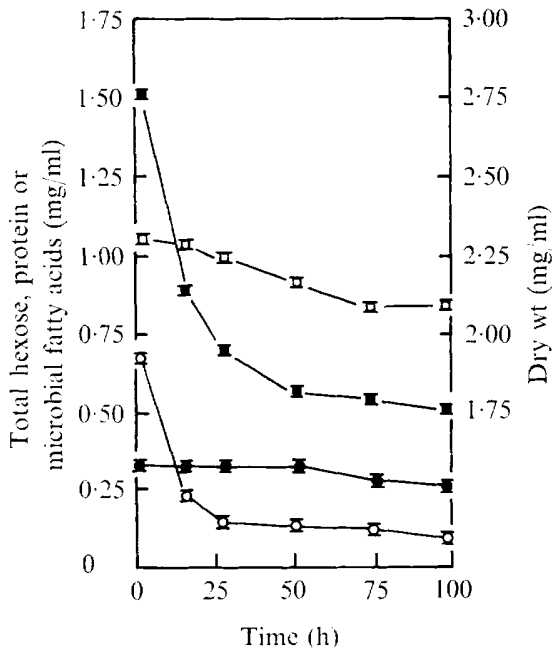

Fig. 3

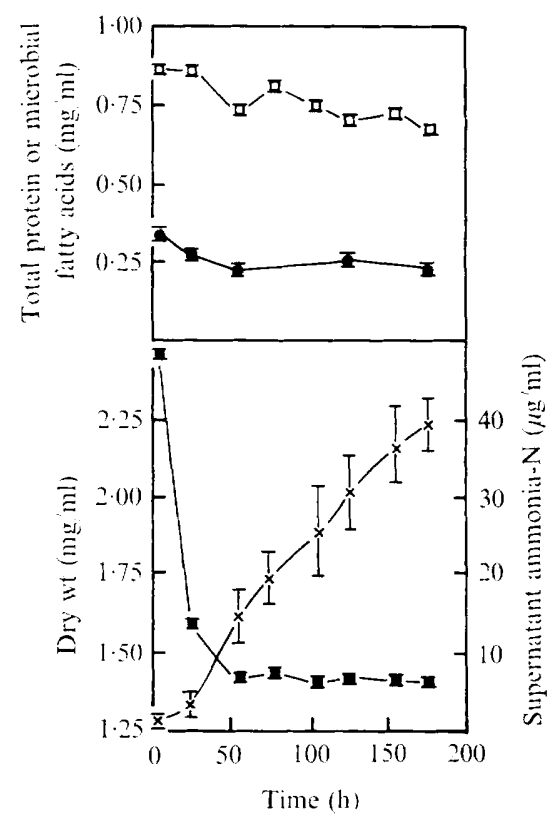

Fig. 4

Fig. 3. Degradation of constituents in starved Nocardia corallina. Organisms suspended in phosphate buffer were incubated at $30{ }^{\circ} \mathrm{C}$ with shaking for $98 \mathrm{~h}$. The means and standard errors of results of single analyses on each of three suspensions are presented. Total hexose $(\bigcirc)$; total protein $(\square)$; microbial fatty acids (O); dry wt (0).

Fig. 4. Degradation of constituents in starved Nocardia corallina. Organisms suspended in phosphate buffer were incubated at $30^{\circ} \mathrm{C}$ with shaking for $176 \mathrm{~h}$. The means and standard errors of results of single analyses on each of two suspensions are presented. Total protein $(\square)$; microbial fatty acids (O); dry wt (ם); supernatant ammonia-N ( $\times$ ).

$(37 \mu \mathrm{g} / \mathrm{ml})$ present in the supernatant after $176 \mathrm{~h}$ was comparable with the theoretical yield of ammonia-nitrogen $(30 \mu \mathrm{g} / \mathrm{ml})$ if it was assumed that all the nitrogen from the degraded protein was excreted as ammonia.

Excretion of ammonia succeeded the depletion of microbial reducing sugar (Fig. 5) of which only $\mathrm{I} \%$ occurred as free reducing sugar. Hence, during the first $48 \mathrm{~h}$ of starvation, microbial polysaccharide was degraded with corresponding retention of nitrogen. After the degradation of polysaccharide ammonia was released from the organisms.

Initial experiments indicated a marked fall in microbial amino acids during the first $24 \mathrm{~h}$ of starvation. Microbial RNA fell from 4 to $\mathrm{I} \%$ of the initial dry wt of organisms over a period of I I days. Material, absorbing in the u.v. region with 260/230 and 260/280 ratios of $\mathrm{I} \cdot 20$ and $2 \cdot \mathrm{I} 7$ respectively, was excreted into the supernatant during starvation.

\section{DISCUSSION}

The potential of Nocardia corallina to survive starvation in liquid medium appears somewhat greater than that of other organisms studied (Ensign, 1970) with the exception of species of Arthrobacter. The greater resistance to starvation of Arthrobacter crystallopoietes in comparison with Nocardia corallina might be related to differences in the time of harvesting organisms for starvation experiments. Arthrobacter crystallopoietes was least 


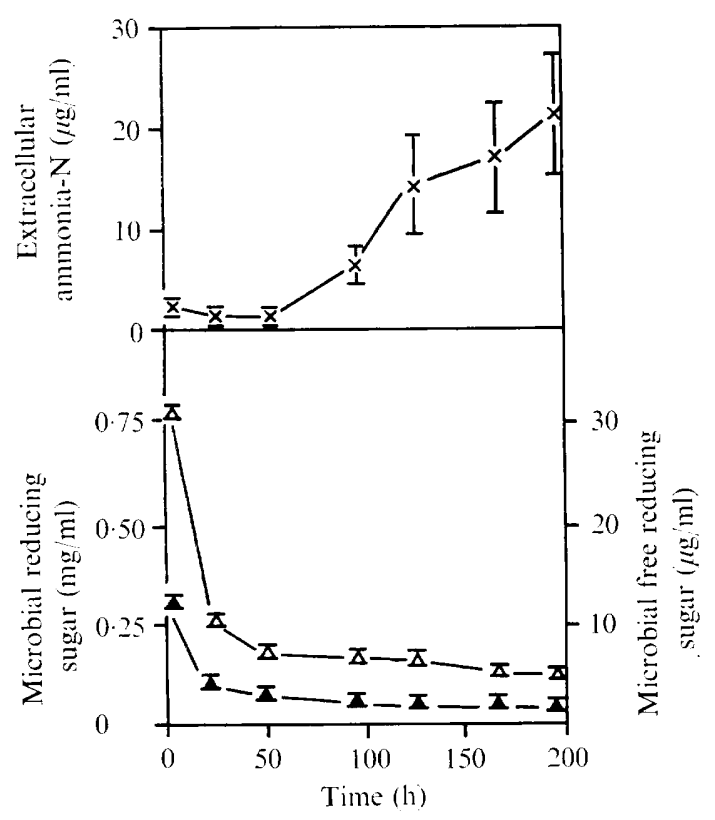

Fig. 5. Degradation of constituents in starved Nocardia corallina. Organisms suspended in phosphate buffer were incubated at $30^{\circ} \mathrm{C}$ for $195 \mathrm{~h}$. The means and standard errors of results of single analyses on each of three suspensions are presented. Microbial reducing sugar $(\Delta)$; microbial free reducing sugar $(\Delta)$; supernatant ammonia- $\mathrm{N}(\times)$.

resistant to starvation in liquid medium when harvested towards the end of the growth phase. In the present study $N$. corallina was routinely harvested at the end of the growth phase and the effect of varying the time of harvesting on resistance to starvation was not examined. The possibility that viability of $N$. corallina was to some degree maintained by leakage of nutrient materials from non-viable organisms was not excluded.

Both Nocardia corallina and species of Arthrobacter showed patterns of endogenous metabolism similar to those of organisms which lose viability more rapidly (Boylen \& Ensign, I970). This pattern appears to be one in which carbon-containing polymers are degraded soon after the organisms are subjected to starvation with corresponding conservation of protein-nitrogen. After the degradation of accumulated carbon polymers, protein and RNA are degraded when ammonia and products of RNA degradation are excreted into the supernatant.

Degradation of lipids other than poly- $\beta$-hydroxy butyrate (Wilkinson \& Munro, I967) during starvation of micro-organisms appears uncommon and was not detected in Nocardia rugosa (Bardi \& Boretti, 1958). Further study was required to relate the small reduction in microbial fatty acids in Nocardia corallina to a particular class of fatty acids (Batt, Hodges \& Robertson, I97I). Determination of the respiratory quotient of starved organisms gave no indication that fatty acids were a predominant carbon source at any time.

Although the patterns of endogenous metabolism of organisms with short and long survival times are similar there is a marked difference in the rates of endogenous metabolism (Boylen \& Ensign, 1970). In Nocardia corallina, at least under the conditions of starvation described, the rate of oxygen consumption, carbohydrate degradation and release of ammonia were approximately five times slower than was reported for Escherichia coli 
(Dawes \& Ribbons, I965). The $50 \%$ survival time of $N$. corallina was approximately five times that of $E$. coli. Loss of viability may therefore be related to the rate at which constituents are metabolized rather than to the absolute level of a particular constituent at the time of starvation. It is possible that autochthonous organisms such as $N$. corallina and A. crystallopoietes have a mechanism for reducing the rate of endogenous metabolism which enhances the likelihood of survival during conditions of starvation.

We are grateful to Dr Ruth Gordon, Rutgers University, for reconfirming the identity of the organism and to Dr R. T. J. Clarke, Applied Biochemistry Division, D.S.I.R. for helpful advice.

\section{REFERENCES}

Alexander, M. (1964). Biochemical ecology of soil microorganisms. Annual Review of Microbiology 18, 217-252.

AmENTA, J. S. (1964). A rapid chemical method for quantification of lipids separated by thin-layer chromatography. Journal of Lipid Research 5, 270-272.

BAILEY, R. W. (I967). Loss of ingested plant carbohydrates from the reticulo-rumen. New Zealand Journal of Agricultural Science 10, I5-32.

BARDI, U. \& BORETTI, G. (1958). Endogenous metabolism of a proactinomyces: Nocardia rugosa. Giornale di Microbiologia 6, 9I-102.

Batt, R. D., Hodges, R. \& Robertson, J. G. (1971). Gas chromatography and mass spectrometry of the trimethylsilyl ether methyl ester derivatives of long chain hydroxy acids from Nocardia corallina. Biochimica et biophysica acta 239, 368-373.

BatT, R. D. \& Woods, D. D. (195I). The oxidation of thymine by an unidentified bacterium. Biochemical Journal 49, ixx.

Boylen, C. W. \& ENSIGN, J. C. (1970). Intracellular substrates for endogenous metabolism during longterm starvation of rod and spherical cells of Arthrobacter crystallopoietes. Journal of Bacteriology 103, $578-587$.

Brock, T. D. (1966). Principles of Microbial Ecology, p. 8I. Englewood Cliffs, New Jersey: Prentice Hall.

Brown, O. \& Clark, J. B. (1966). Fragmentation in Nocardia corallina. Journal of General Microbiology 45, 525-530.

CLARK, F. E. (1967). Bacteria in soil. In Soil Biology, p. 15. Edited by A. Burgess and F. Raw. London and New York: Academic Press.

ClARK, J. B. (1958). Slime as a possible factor in cell clumping in Nocardia corallina. Journal of Bacteriology 75, 400-402.

Clark, J. B. \& Frady, J. (1957). Secondary life cycle of Nocardia corallina. Journal of Bacteriology 74, 698.

ConN, H. J. (1948). The most abundant groups of bacteria in soil. Bacteriological Reviews 12, 257-273.

Conway, E. J. (1947). Microdiffusion Analysis and Volumetric Error, 4th edn, p. 90. London: Crosby, Lockwood and Son.

Corman, J., Tsuchiya, H. M., Koepsel.l, H. J., Benedict, R. G., Kelly, S. E., Feger, V. H., Dworschack, R. G. \& JACKSON, R. W. (1957). Oxygen absorption rates in laboratory and pilot-plant equipment. Applied Microbiology 5, 313-318.

Dawes, E. A. \& Ribbons, D. W. (1962). Endogenous metabolism of micro-organisms. Annual Review of Microbiology 16, 24I-264.

Dawes, E. A. \& RibBons, D. W. (1965). Studies on the endogenous metabolism of Escherichia coli. Biochemical Journal 95, 332-343.

ENSIGN, J. C. (1970). Long-term starvation survival of rod and spherical cells of Arthrobacter crystallopoietes. Journal of Bacteriology 103, 569-577.

GoRDON, R. E. (1966). Some strains in search of a Genus - Corynebacterium, Mycobacterium, Nocardia or what? Journal of General Microbiology 43, 329-343.

Gordon, R. E. (1967). Ecology of Soil Bacteria, p. 293. Liverpool: University Press.

Holden, J. T. (1962). In Amino Acid Pools, p. Ior. Edited by J. T. Holden. Amsterdam: Elsevier.

Lamanna, C. (1963). Studies of endogenous metabolism in bacteriology. Annals of the New York Academy of Sciences 102, 517-520. 
Midwinter, G. G. (1962). Metabolism of Nocardia corallina. Ph.D. Thesis, University of Otago, New Zealand.

Midwinter, G. G. \& BATt, R. D. (1960). Endogenous respiration and oxidative assimilation in Nocardia corallina. Journal of Bacteriology 79, 9-1 7 .

Munro, H. N. \& Fleck, A. (1966). In Methods of Biochemical Analysis, vol. I4, p. I 13. Edited by D. Glick. New York: Inter-science.

Nelson, N. (1944). A photometric adaptation of the Somogyi method for the determination of glucose. Journal of Biological Chemistry 153, 375-380.

PARK, D. (1965). Survival of micro-organisms in soil. In Ecology of Soil-Borne Plant Pathogens, pp. 82-98. Edited by K. F. Baker and W. C. Snyder. London: John Murray.

Postgate, J. R., Crumpton, J. E. \& Hunter, J. R. (I96I). The measurement of bacterial viabilities by slide culture. Journal of General Microbiology 24, I 5-24.

Rosen, H. (1957). A modified ninhydrin colorimetric analysis for amino acids. Archives of Biochemistry and Biophysics 67, 10-15.

Salton, M. R. J. (I953). Studies of the bacterial cell wall. IV. The composition of the cell walls of some Gram-positive and Gram-negative bacteria. Biochimica et biophysica acta 10, 512-523.

SNEATH, P. H. A. (1962). Longevity of micro-organisms. Nature, London I95, 643-646.

STICKLAND, L. H. (I95I). The determination of small quantities of bacteria by means of the biuret reaction. Journal of General Microbiology 5, 698-703.

Tepper, E. Z. \& Karyagina, L. A. (I966). Use by Protoactinomyces of a number of aromatic substances occurring in soils together with plant residues and humic substances. Dokl. TSKhA (Timiryazev. Seliskolkhoz. Akad.) Ir9, 21 7-224.

Thomas, V. J., Doughty, N. A., Fletcher, R. H. \& Robertson, J. G. (1972). Estimation of microbial viability. Biometrics 28, 947-958.

Umbreit, W. W., Burris, R. H. \& Stauffer, J. F. (1964). Manometric Techniques, 4th edn. Minneapolis: Burgess Publishing Co.

Waksman, S. A. (1959). The Actinomycetes, vol. I. Baltimore: Williams and Wilkins.

Webb, R. B. \& Clark, J. B. (1957). Cytogenetic study of Nocardia corallina. Journal of Bacteriology 74, $3 \mathrm{I}-42$.

Wilkinson, J. F. \& Munro, A. L. S. (1967). In Microbial Physiology and Continuous Culture. Proceedings of the Third International Symposium, p. I73. Edited by E. O. Powell, C. G. T. Evans, R. S. Strange and D. W. Tempest. London: Her Majesty's Stationery Office.

Zevenhuizen, L. P. T. M. (1966). Formation and function of the glycogen-like polysaccharide of Arthrobacter. Antonie van Leeuwenhoek 32, 356-372. 